\title{
Women in Action: The Role of Shg in Women Empowerment in Goalpara District, Assam
}

\author{
Rakesh Chetry \\ Department of Geography, Gauhati University, India
}

\begin{abstract}
Since the late mid-twentieth century, the concept and action of women empowerment have gained popularity. Scholars particularly feminists have emphasized upon the ways and means for upholding the dignity and position of the women in society. Self Help Group $(S H G)$ is such a platform, which have since its inception in 1976, proved a big success in hastening economic growth and development of the whole nation by bringing together the members of the society in a collective fashion. As most of the SHG's in India are rural-centric and women-oriented, this in turn has helped in speeding up the progress of the women folk, who were left behind since history. However the performance of SHG does differ with respect to a particular community as well as with geographical area. Thus the main intention of the paper is to examine the role of SHG's in women empowerment at the selected villages under Rangjuli Revenue Circle of Goalpara district of Assam. The study is rural-centric and specifically focuses upon women group, as they are deemed to be the most vulnerable section of the society. Basically based upon primary survey, the study suggests that about 83 per cent of the surveyed women folk (out of total 188 women members) have benefitted much and feel empowered after being associated with SHG. Infact SHG's have casted its influence upon their personal as well as social life, rendering them respectful position in the family as well as community at large.
\end{abstract}

Key words: Rangjuli, Rural-centric, Self Help Group, Women empowerment.

\section{Introduction Of The Study:}

Women empowerment is a much discussed and popular term at the present age, since it encompasses and is concerned with almost half of mankind, who were since ages subdued and browbeaten either in the name of the family, traditions, rituals, etc. Empowerment in general is a process of shift in space of an individual-be it physical, economic or political at large. 'Increase in space', means enhancing the sphere of influence of an individual, which is itself determined by the physical and social environment which surrounds him/her. 'Space' infact determines one's thoughts and actions within and outside his milieu.

Space which is connotative to power, is itself controlled by the economic and socio-cultural background of the individual concerned. Although the socio-cultural aspects such as family hierarchy (whether joint or nuclear), age, marital status, caste and class, ethnic origin etc. can't be altered, but the economic status of the individual which largely manipulates the physical, social and political relationship in the society, can be easily enhanced. Here the role of SHG comes into play, where members of the community basically women, sharing similar concerns come together and form a group of 10-20 persons, with the intention of saving and rotating loans amongst themselves and others, charging a nominal interest rate, thereby making them economically strong and sound. Economic security in turn helps in increasing their physical space which is basically thought to be the four-walls of the kitchen. Access to government offices, financial institutions, training centre (educational or vocational, agricultural/non-agricultural), can be translated into access to physical geographical space, the existence and quality of which can be evaluated as an indicator of empowerment (Joy Deshmukh-Ranadive, 2005). Not only their physical space, but involvement with SHG also tends to increase their economic space, thereby leading to more access, control and ownership of economic goods and services.

In addition, through participation in SHG, women become more extrovert, which leads to development of better communicative skills and leadership quality. Consequently there is also enhancement of political space among women, through their easy access to political institutions and control of public offices.

\section{Objectives Of The Study:}

As the title of the research paper suggests, the main purpose of the study is to analyze the role of Self Help Groups (SHG's) in empowering and stirring the family and societal status of the women folk especially from rural background. The target groups being rural women are considered as the most vulnerable sections of the society easily prone to exploitation and oppression both in the hands of family and community. This in turn will reveal the actual field scenario of the works and deeds of the SHG in women emancipation. 


\section{Database And Methodology:}

The study undertaken is primarily based on Primary data collected through survey with the help of a concise and precise schedule cum questionnaire. The questions incorporated in the questionnaire are purpose oriented and are based on the pre-field visit and shared experiences. The necessary secondary data has been gathered from various publications of financial institutions and NGOs' including Block Development Reports, books, journals and different government websites. As many as 47 SHG's have been selected covering 35 villages with altogether 188 respondents (4 respondents per SHG). The villages have been selected randomly based on their connectivity. The respondents include the President of the SHG including its 3 other members who have been associated with the group for at least the last 3 years. The data so collected have been arranged, tabulated and processed using simple statistical techniques such as the absolute percentage method. Necessary maps and diagrams have also been included, for clear exposition of the problem.

\section{A Brief Background Of The Study Area:}

The study area comprises of Rangjuli Revenue circle of Goalpara district of west Assam. Bounded by the Kamrup district in the east; Dudhnoi revenue circle and Meghalaya in the west; Matia revenue circle in the North; and Meghalaya in the south, the Rangjuli revenue circle encompasses about 15.16 per cent of the total area of the district while accommodating a total of about 1.09 lakh population, which are predominantly of rural background. Entirely composed of alluvial tract, with clayey soil in the south bordering the Meghalaya plateau, agriculture is the main economic activity of more than 80 per cent of the population. The region is covered with moist deciduous vegetation due to the prevalence of monsoon type of climate. The area is basically drained by the Brahmaputra and its tributary- Deosila, which originates from the Meghalaya Plateau.

The region is demographically significant as it is predominantly occupied by the tribal and scheduled caste population. The Scheduled Tribe (ST) and Scheduled Caste (SC) group constitutes about 38 per cent and 12 per cent of the total population of the Rangjuli Revenue Circle with predominant tribal groups being Rabha, Bodo, Garo etc. in addition with Koch Rajbonsis (not yet recognized as ST till date).

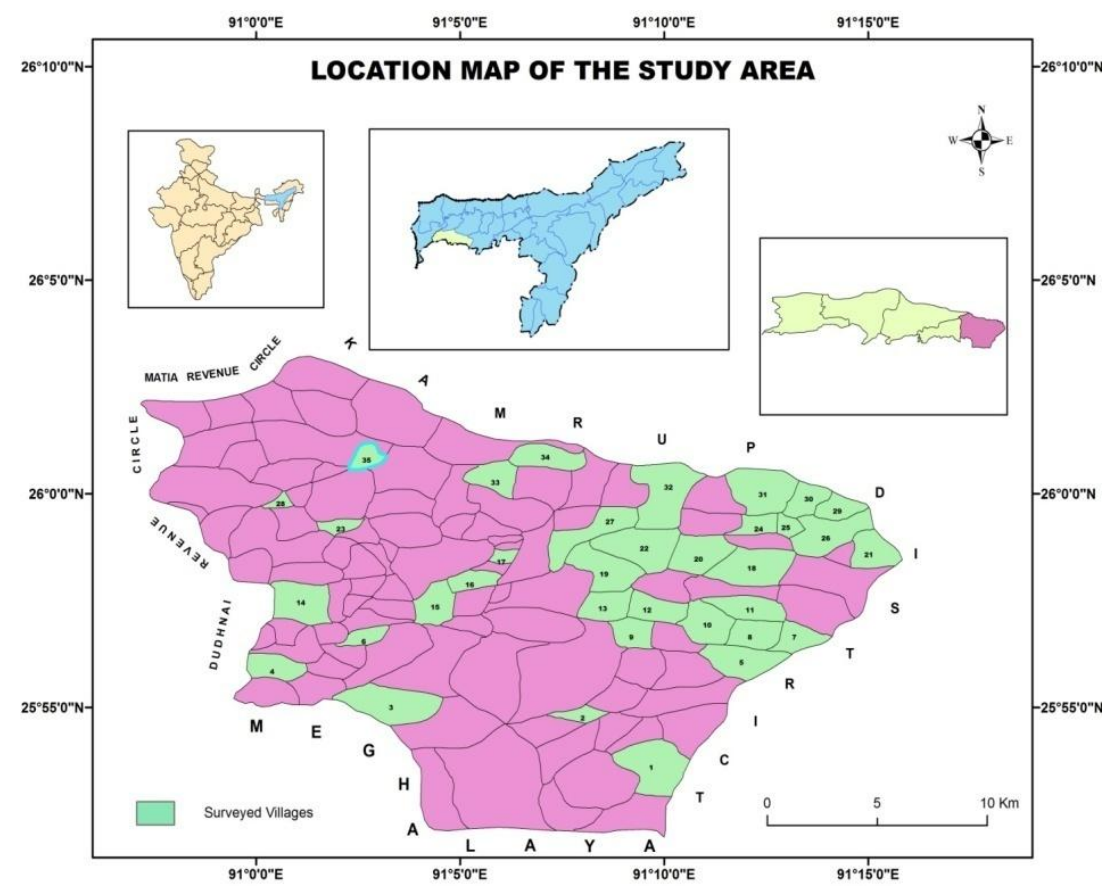

List of the Villages, where SHGs have been located and surveyed:

\begin{tabular}{|l|l|l|l|l|l|l|}
\hline 1. Ambari Pt III & 6. Sarapara Pt. I & $\begin{array}{l}\text { 11. Dhigali } \\
\text { Pt. II }\end{array}$ & 16. Fakirpara & 21. Ghilabari & 26. Bardol Pt. I & 31 Khutabari Pt. I \\
\hline $\begin{array}{l}\text { 2. Shymagaon } \\
\text { Pt I }\end{array}$ & $\begin{array}{l}\text { 7. Dhupdhara } \\
\text { Pt. III }\end{array}$ & 12. Maslam & 17. Khamar & $\begin{array}{l}\text { 22. Ambari } \\
\text { Pt. II }\end{array}$ & 27. Dhontola Pt. I & 32. Ambari Pt. III \\
\hline $\begin{array}{l}\text { 3. Sildubipara } \\
\text { Pt 1 }\end{array}$ & 8. Dhigali Pt. I & 13. Khekapara & 18. Piplibari & 23. Bhalukjuli & 28.Saukapara Kahibari & 33. Bangaon \\
\hline 4. Adopara & 9. Barbari & 14. Garopara & $\begin{array}{l}\text { 19. Ambari } \\
\text { Pt. IV }\end{array}$ & $\begin{array}{l}\text { 24. Khutabari } \\
\text { Pt II }\end{array}$ & 29. Talipara Kauridubi & $\begin{array}{l}\text { 34. } \\
\text { Choutra } \\
\text { Naitarabeel }\end{array}$ \\
\hline $\begin{array}{l}\text { 5. Khutabari } \\
\text { Pt IV }\end{array}$ & $\begin{array}{lllll}\text { 10. Dhigali } \\
\text { Pt III }\end{array}$ & $\begin{array}{l}\text { 15. Patpara } \\
\text { Pt. II }\end{array}$ & $\begin{array}{l}\text { 20. Ambari } \\
\text { Pt. I }\end{array}$ & $\begin{array}{l}\text { 25. Khutabari } \\
\text { Pt. III }\end{array}$ & $\begin{array}{l}\text { 30. Khutabari } \\
\text { Pt. V }\end{array}$ & $\begin{array}{l}\text { 35. } \\
\text { Pahar }\end{array}$ \\
\hline
\end{tabular}




\title{
V. Analysis And Discussion:
}

SHG and the Status of Women: A Synergistic Linkage

'Millions of women in our hamlets know what unemployment means. Give them access to economic activities and they will have access to power and self-confidence to which they hitherto have been strangers' (Mahatma Gandhi). As stated earlier, the Rangjuli Revenue Circle comprises of 126 villages, with no urban centre. Mostly the women folk are confined to household activities with 74.63 per cent of the females unemployed. Since confined within the four walls of the household throughout ages, they have been left behind the mainstream, when compared to their opposite sex. In this context, SHG have done a laudable work in empowering and bringing rural women to the mainstream thereby changing their outlook as well as attitude towards the society. SHG's have brought the rural women folk out of their so called kitchen cocoons, and made them socially, politically and economically empowered, demanding respect and attention from their society in general and family in particular.

However in the present study, most of the respondents (about 42 per cent) have approved of the fact that they have joined SHG in order to maintain their household expenditure and support the family economically. Therefore it is rightly said that women will be women- the home and the family without which she considers herself to be incomplete. Infact about 32 per cent of the respondents have been associated with SHG to get loans from it and repay their old debts, generally borrowed by their husbands. When enquired, whether they have joined SHG for self-development, only 6 respondents (about 3 per cent of the total) reciprocated in positive. Moreover about 6 per cent of the surveyed women have got themselves admitted to SHG unwillingly, at the word of their spouse.

Table 1: Reason Behind Joining Shg Of Women Folk In Selected Villages Of Rangjuli, 20122013

Source: Based on Field study

\begin{tabular}{|c|l|c|c|}
\hline S1. No & \multicolumn{1}{|c|}{ Statement } & No. of members & Members in per cent \\
\hline 1 & To maintain household expenditure & 58 & 30.85 \\
\hline 2 & For borrowing loans in low interest rate & 48 & 25.53 \\
\hline 3 & For promoting social status & 32 & 17.02 \\
\hline 4 & For supporting family and promoting savings & 21 & 11.17 \\
\hline 5 & To repay old debts & 12 & 6.38 \\
\hline 6 & On the word of the husband & 11 & 5.85 \\
\hline 7 & For self-development and empowerment & 06 & 3.20 \\
\hline 8 & Total & 188 & 100 \\
\hline
\end{tabular}

Fig. 1: REASON BEHIND JOINING SHG IN RANGJULI, 2012-2013

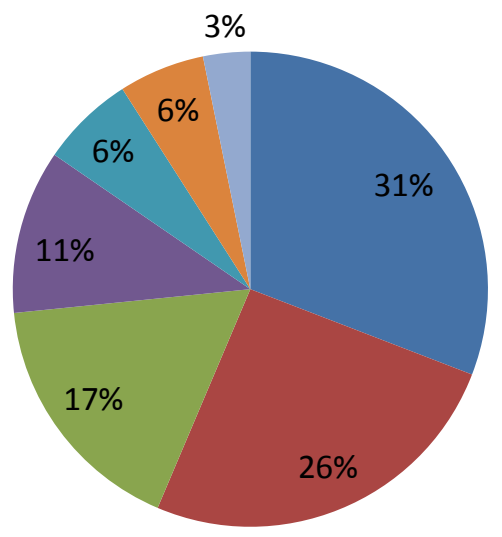

\author{
STATEMEN \\ TS \\ - To maintain Household expenditure \\ - For borrowing loans in low interest rate \\ - For promoting social status \\ - For supporting family and promoting savings \\ - To repay old debts \\ - On the word of the husband \\ - For self-development and empowerment
}

From the figure, it is evident that most of the women have joined the SHG not for self-development or empowerment but to fulfill the household needs, which the spouses were unable to accomplish. Although needbased, these aspects in the long run are believed to empower the rural women folk.

\section{Economic Interdependence And Space Relationship With Shg:}

One of the most important stimuli of empowerment is economic soundness which altogether alters the social fabric of an individual. As most of the women surveyed are from interior villages, they have very limited access and control of the economic goods and services of the household and the society at large. They become petitioners if not beggars to their spouse for any monetary item they require-however small it might be. This in 
turn tends to demean their self-respect and self-esteem, consequently degrading their position both in family as well as society. In this context, interventions such as those of SHG's can lead a long way in eradicating the economic constraints, thereby empowering them economically.

An analysis of the income pattern of the respondents before and after joining SHG reveals a remarkable positive shift in their earning behavior. Before joining SHG, about 77 per cent of the respondents were dependents with limited earning avenues. However after joining SHG, besides the monthly savings in banks, all the respondents got themselves engaged in the undertaken schemes be it piggery (rearing of pigs), goattery (rearing of goats), handicrafts, poultry, dairy etc. Infact before joining SHG, only 12 women out of the total considered women folk were earning a monthly income below Rs. 500/-, but in the post-SHG period, a total of 122 members (65 per cent) are earning more than that petty amount. Similarly there has been remarkable growth (400 per cent) in the number of women members, earning a monthly income of above Rs. 2000/-, before and after joining SHG.

Table 2: Monthly Earning Of Members Before And After Joining Shg In Rangjuli, 2012-2013

\begin{tabular}{|c|c|c|c|c|c|}
\hline \multirow[t]{2}{*}{ Monthly Income } & \multicolumn{2}{|c|}{ Pre-SHG Period } & \multicolumn{2}{|c|}{ Post-SHG Period } & \multirow{2}{*}{$\begin{array}{l}\text { Percentage } \\
\text { increase }\end{array}$} \\
\hline & No. of respondents & Percentage & No. of respondents & Percentage & \\
\hline No Income & 144 & 76.60 & - & - & - \\
\hline Below 500 & 12 & 6.38 & 66 & 35.11 & 450 \\
\hline $500-1000$ & 17 & 9.04 & 51 & 27.13 & 200 \\
\hline $1000-1500$ & 5 & 2.66 & 24 & 12.77 & 380 \\
\hline $1500-2000$ & 7 & 3.72 & 32 & 17.01 & 357 \\
\hline Above 2000 & 3 & 1.60 & 15 & 7.98 & 400 \\
\hline Total & 188 & 100 & 188 & 100 & \\
\hline
\end{tabular}

Source: Based on Field study

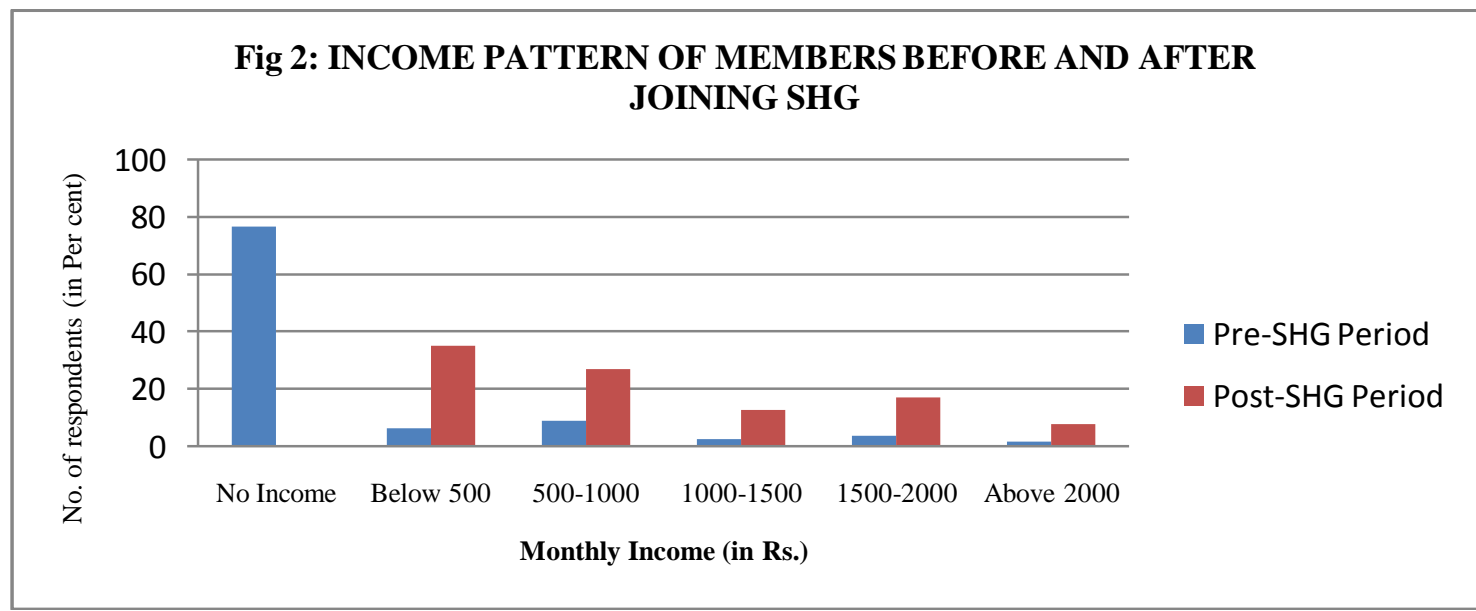

Not only through the undertaken schemes, but the members also avail monetary loans from various micro-financial institutions like Bandhan, Rashtriya Gramin Vikas Nidhi (RGVN), Proceshta, AMTRON etc., and from the SHG itself. The SHG in turn charges a minimal rate of interest (ranges from Rs. 2 to 3 per Rs. $100 /$ month) upon the money borrowed by any member of the SHG itself. However, this interest rate is somewhat high (ranges from Rs. 15 to 25 per Rs. 100/month) for outsiders (non-members), who have availed loan from the SHG.

Table 3: Loan Availed By The Members And Non-Members Through Shg In Rangjuli, 2012-

2013

\begin{tabular}{|c|l|c|c|c|}
\hline Sl. No & Loan Availed (in Rs.) & No. of Members & Percentage & No. of non-members \\
\hline 1 & Below 5000 & 45 & 23.90 & 9 \\
\hline 2 & $5000-10,000$ & 11 & 5.85 & 3 \\
\hline 3 & $10,000-15,000$ & 23 & 12.20 & 15 \\
\hline 4 & $15,000-20,000$ & 8 & 4.26 & 2 \\
\hline 5 & Above 20,000 & 14 & 7.45 & 2 \\
\hline 6 & Total & 101 & 53.70 & 31 \\
\hline
\end{tabular}

Source: Based on field survey.

The above table reveals that about 54 per cent of the total surveyed members of the SHG have availed loan from it within the time period 2012-2013. It is to be mentioned that at a particular time, any number of members can avail loan from the SHG based on the availability of funds in its account. Similarly outsiders (non- 
members) who borrow money from SHG must be sponsored by any of the existing member of the group. Many SHG's do not lend money beyond Rs. 15,000/- to outsiders.

\section{Self Help Group And Women Empowerment In Rangjuli Revenue Circle}

Empowerment is a process whereby constraints that impede equal participation are reduced so that the inequality starts moving towards becoming equality (Joy Deshmukh-Ranadive, 2005). Without women emancipation and upliftment of about half of mankind, a society or a nation cannot progress in true sense. In this context, Gandhiji rightly remarked, "One step for women, ten steps for nation".

Based on 9 indicators of empowerment, viz. increased income, better status in family and society, skill development, improved standard of living, better communication skill and leadership quality, more awareness in health, education and other associated issues, understand the banking operations, economic independence and lastly increase in self-confidence, the role of SHG has been evaluated in upgrading the family and societal status of rural women in the study region. Recommend ably overall 83 per cent of the respondents approved of the fact that SHG has empowered them in the above nine said aspects; whereas only 3.4 per cent of them responded in negative.

Table 4: Perception Of Empowerment Of The Respondents Based On Some Selected Indicators

\begin{tabular}{|c|c|c|c|c|c|c|c|}
\hline $\begin{array}{l}\text { Sl.N } \\
\text { o }\end{array}$ & Indicators of Empowerment & Agree & $\begin{array}{l}\text { Percentag } \\
\text { e }\end{array}$ & $\begin{array}{l}\text { Disagre } \\
\mathrm{e}\end{array}$ & $\begin{array}{l}\text { Percentag } \\
\text { e }\end{array}$ & No Response & Percentage \\
\hline 1 & Increased income & 176 & 93.62 & 03 & 1.60 & 09 & 4.78 \\
\hline 2 & Better status in family and society & 145 & 77.13 & 16 & 8.51 & 27 & 14.36 \\
\hline 3 & Skill development & 121 & 64.36 & 08 & 4.26 & 59 & 31.38 \\
\hline 4 & Improved standard of living & 147 & 78.19 & 09 & 4.79 & 32 & 17.02 \\
\hline 5 & Better communication skill and leadership quality & 134 & 71.28 & 00 & & 54 & 28.72 \\
\hline 6 & $\begin{array}{l}\text { Awareness in health, education and other associated } \\
\text { issues }\end{array}$ & 181 & 96.28 & 00 & & 07 & 3.72 \\
\hline 7 & Understand the banking operations & 185 & 98.41 & 00 & & 03 & 1.59 \\
\hline 8 & Economic independence & 152 & 80.85 & 06 & 3.19 & 30 & 15.96 \\
\hline 9 & Increase in self-confidence & 158 & 84.04 & 14 & 7.45 & 16 & 8.51 \\
\hline \multicolumn{2}{|c|}{ Total } & 1399 & & 56 & & 237 & \\
\hline \multicolumn{2}{|c|}{ Average } & 155 & & 7 & & 26 & 188 \\
\hline \multicolumn{2}{|c|}{ Percentage of average } & 82.60 & & 3.40 & & 14.0 & 100 \\
\hline
\end{tabular}

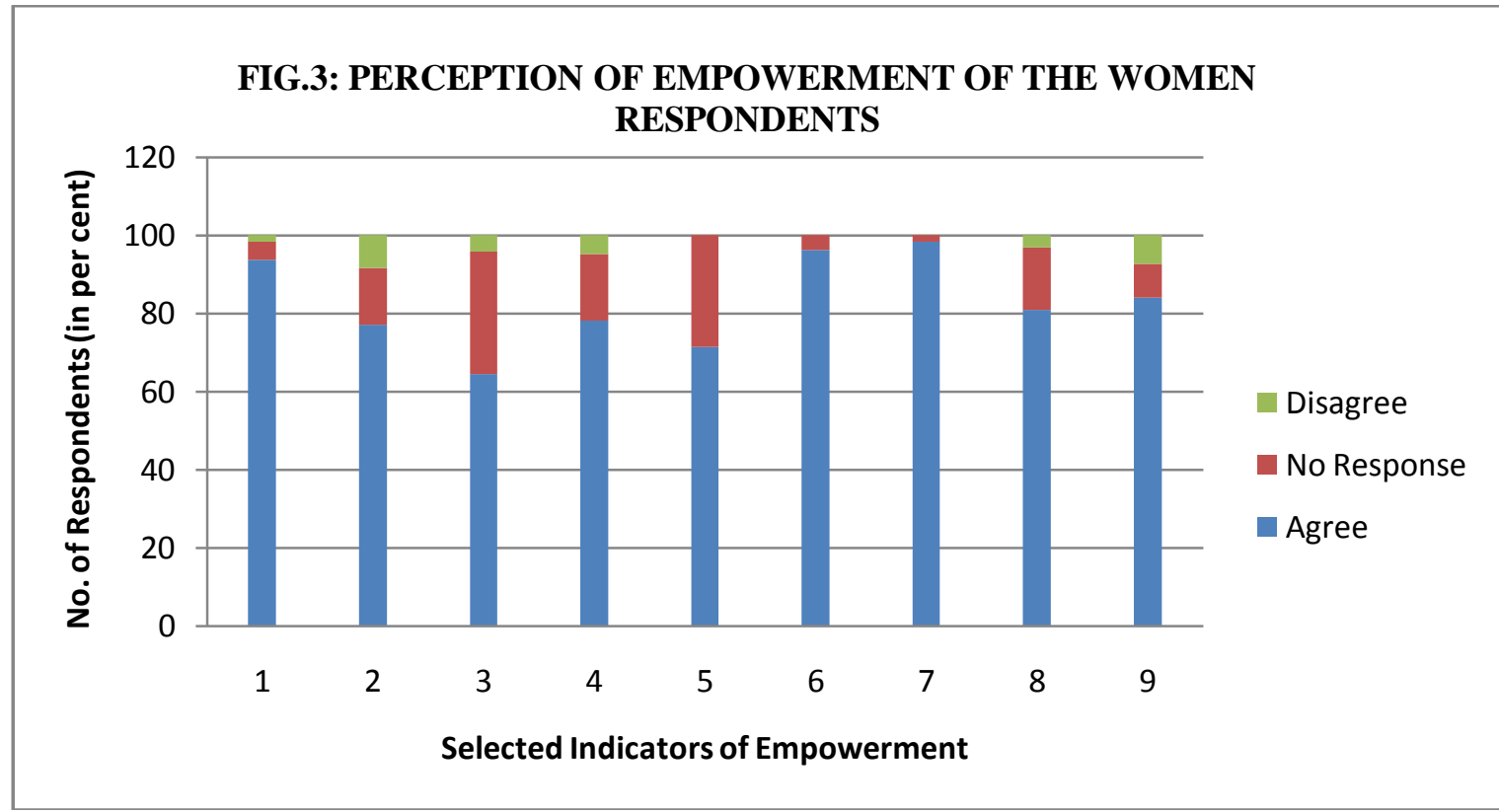

Specifically almost 98.41 and 96.28 per cent of the respondents are of the opinion that SHG has helped them in understanding banking operations and have aided in generating awareness in health, education and other related issues respectively. Similarly 93.62 per cent of the women have opined that SHG has helped them to earn and increase their income, however minimal it might be. However with respect to better skill development and improvement of communicative and leadership quality, only 64.36 per cent and 71.28 per cent of the respondents affirmed in positive. It is noteworthy that about 9 per cent of the surveyed women held the view that SHG has failed in elevating their status either in family or in society. 
The main cause behind such negative responses is the joint family system, where the elderly members of the family have the sway in almost all the aspects. Moreover out of the 16 respondents (of indicator No. 2), 12 respondents are from economically sound family, whose spouse are either good businessman or are engaged in government services. This leads to economic dominance of the husbands over their wives, for which their words are unheard or rather neglected. But barring few loopholes, it must be appreciated that the SHG scheme has indeed in true sense empowered the rural women folk both economically, socially and politically and in turn increased their sphere of influence or space.

\section{Conclusion:}

To conclude, the role of SHG in women emancipation of rural women folk is a revolution in itself, which has undoubtedly benefitted its members in real sense. Through SHG, the women members have been able to put up their voice in any platform-from family to community at large. They have learned to earn and handle economic assets in a more reasonable way. The illiterate members of the SHG, being subdued since ages, have been able to garner importance in their family and dare the patriarchal convention. Thus more and more women participation in SHG should be promoted and infact required for the whole region to delve in the path of progress and achievement, as development is itself a holistic term which can't be achieved without proper coordination and cooperation between the two gender groups. Moreover the governance body must ensure that the backward and poor sections of the society get adequate representation in the SHG, so that the SHG doesn't become a chamber of aristocratic women, and unfortunately if this happens, the real objective of SHG in empowering the backward class will remain a distant dream, difficult if not impossible to be fulfilled.

\section{Acknowledgements}

I acknowledge the help and assistance of Shri Lakshyadhar Das in successfully carrying out the field survey in the said areas. Without his association, the field work would have been tiresome and lengthy. I also admit the assistance of Miss Sutapa Bhattacharjee and Miss Shibani Basumatary in preparation of the map of the study area. Lastly I thank the respondents for sparing their time and for listening patiently and answering our questionnaire.

\section{References}

[1]. S.J. Anand, Self Help Groups in Empowering Women: Case Study of selected SHGs and NHGs, Kerela Research Programme on Local level Development, Centre for Development Studies, Thiruvananthapuram, 2002, Discussion Paper No. 38.

[2]. M. Anjugam and C. Ramasamy, Determinants of Women's Participation in SHG-led Microfinance Programme in Tamil Nadu, Agricultural Economics Research Review. 20 (2), 2007, 283-298.

[3]. J. Deshmukh-Ranadive, Women in SHGs and PRIs: Suggesting Synergistic Linkages, Occassional Discussion Paper No. 40. Centre for Women's and Development Studies (CWDS), New Delhi,2005.

[4]. D. Humle and P. Mosley Finance against Poverty (London: Routledge Publications, 1996).

[5]. K. Kondal, Women Empowerment through Self Help Groups in Andhra Pradesh, India. International Research Journal of Social Sciences, 3(1), 2014, 13-16. Available from www.isca.in [Accessed on 25/08/2014]

[6]. T. Nair, and A. Tankha, Microfinance India State of the Sector Report, 2013, (Sage Publications, New Delhi, 2014).

[7]. G.N. Sarmah and D.K. Das, Microfinance, SHGs and Socio-Economic Development of Rural people (A case study with special reference to the Lakhimpur District of Assam), Asian Journal of Research in Business Economics and Management, 2 (4), 2012, $145-159$

[8]. Y. Singh, Effect of Self Help Group in Economic Empowerment of Rural Women in Himachal Pradesh, Gender Studies, 1(3),2013, 54-61.

[9]. S. Thangamani, and S. Muthuselvi, A Study of Women Empowerment through Self Help Groups with special reference to Mettupalayam Taluk in Coimbatore District. Journal of Business and Management (IOSR-JBM), 8(6), 2013, 17-24. Available from www.iosrjournals.org [Accessed on 12/04/2014].

[10]. D. Umashankar, Women's Empowerment: Effect of Participation in Self Help Groups. A Dissertation submitted in partial fulfillment of Requirements of Indian Institute of Management, Bangalore for the Post Graduate Programme in Public Policy and Management, 2006.

[11]. J. Venkatesh and K. Kala, Empowering Rural Women all the way through Self Help Groups. International Journal of Management,[Online],1(2),2010,156-163. Available from: http://www.iaeme.com/ijm.html [Accessed 26/08/2014] 